\title{
THE IOWA HISTORICAL DEPARTMENT
}

\author{
By Ora Williams
}

The Iowa Historical Department commenced as a hobby. That is the way of a good many beginnings. A bright young printer got the idea as he was sweeping out the office of a country newspaper. The young man rescued from the waste basket the wrapper of a package thrown there by his employer who had also been his schoolmate at an academy. The employer asked why, and the boy said he was interested in the signature by which the package had been franked. It was the signature of a then famous United States Senator who had placed his name there in lieu of a postage stamp. A newspaper office is a good place for starting a hobby of this kind, and the collection grew. It interested the boss and the apprentice. Its immense possibilities soon became evident and the hobby took definite shape.

The young man who leaned on a broom as he rescued a signature from the waste basket was Charles Aldrich.

The signature thus first noticed was that of Thomas $\mathrm{H}$. Benton of Missouri, the "Old Bullion" of other days, and in due time Charles Aldrich secured a copy of Benton's book, Thirty Years' View, pasted the signature therein, and loaned the book into oblivion. But the hobby was a spirited horse and $\mathrm{Mr}$. Aldrich rode it well and to a final goal not often attained.

The Iowa Department of History and Archives, long and familiarly known to all as the "Iowa Historical Department," is this year celebrating its semicentennial as an organized department of the state. The chief value of this review of its history is that planning for the next fifty years may be better. The Department did not spring forth in full strength as if by some magic touch. Before the official date of the beginning a great deal had been done. It is what was in the minds of a large number of those who had engaged in 
making history or in keeping the record, chief among whom was Charles Aldrich. They formed a pattern that has been closely followed.

It was in Warren, Pennsylvania, that Aldrich picked up his first autograph.The editor who was willing had been a schoolmate in an academy at Jamestown, N. Y. He soon found himself shifting about, after the manner of craftsmen of his time, editing newspapers, getting married and looking with longing eyes to the then far west. Mr. Aldrich tried out his editorial capacity at Olean, N.Y., and elsewhere, and the test was satisfactory. The hobby was nine years old when Aldrich and wife, in 1857, started for the land beyond the big river, without social security number or any guaranty beyond that of willing hands and honest purposes.

Charles Aldrich found himself among kindred spirits in this newly formed frontier society. The men and women were of a type common to the pioneering movement. They had all the varied talents and characteristics essential for the making of a state. It was exceedingly fortunate that Mr. Aldrich, when he edged his way to the very rim of the frontier with a printing press and a valuable hobby, brought with him a wife who was a true helpmate. Together they entered into all the activities of the ambitious folks of Webster City, the newly established county seat of Hamilton County, and in the Hamilton Freeman they made record of the progress of a typical lowa community.

The editorial sanctum of that time was a center of political and cultural activity. The editor not only tried to print the news but he had $a$ hand in moulding public opinion. The era was rich in political currents. In the region from whence Aldrich came the Free Soil movement was rising to its high duty, and in Iowa Mr. Aldrich found the first state admitted into the Union with its soil dedicated to human freedom. The time of compromises was drawing to an end.

Mr. Aldrich became and long continued a newspaper editor of much influence, and as such and as a legislator he came to know lowa history and lowa men in a way most useful to the state. 
The zeal with which the making of a historical collection had been started in 1848 in a small town hemmed in by mountains found greater freedom on the prairies of Iowa. There was much letter writing and many little journeys to the haunts of the great both in the United States and across the ocean. The rare genius that comes with persistence and singleness of purpose yielded rich returns that will be appreciated by many generations of Iowans.

When the building of the state capitol was nearly finished and the commission was buying the furniture, in the early 1880's, Mr. Aldrich instigated the making of two autograph cases sufficient to hold a large part of his collection that had grown steadily through thirty years. They were located in an out-of-the-way place on the basement floor of the capitol but by the time the building itself was formally dedicated Mr. Aldrich had made his nook popular.

These collection cases form the corner stone of the Historical Department. They stand today at the entrance to the main office and have back of them a dozen others filled with material the value of which is beyond estimation. One of these original cases bears a plate on which is inscribed:

The Aldrich Collection. Presented to the State of Iowa by Charles Aldrich and Matilda Williams Aldrich, of Webster City, Hamilton county, June 10, 1884.

The idea of a state historical department was in the mind of Mr. Aldrich long before this, but it was too soon to have it become a reality. The first case contains properly the writings and portraits of the presidents of the United States. But the nineteenth century was notable for its great men and great women and these and the notable personages of Iowa fill the cases.

The craftsmen were still at work on the state capitol when the two cases were set up and Mr. Aldrich borrowed a chair and a desk. He asked and received no compensation for his first work. It was a labor of love for him and his wife. But he knew public men, from having been 
a clerk of the House of Representatives several terms and a member of the legislature from Hamilton County, and the wide acquaintance thus made and his high standing as a newspaper editor with convictions, opened the way for realizing his dreams. He had learned that a man with a vision, even though only the editor of a weekly newspaper, had the power to move mountains by sticking to the job, for indeed it was like moving a mountain to get his dream embodied in a statute, and his autograph collection established as he had wished.

Funds were grudgingly contributed by a legislature to add two more autograph cases and to pay postage as the founder searched for more material that should be reclaimed from waste baskets and musty attics. The job was becoming too big for the founder. The history makers and the history recorders the legislators and the editors, were becoming deeply interested. The next step was to hold a reunion of surviving members of the legislators of the territory and state and others who had held high office. A call was signed by a number of well known men. The response was good and the first reunion opened on February 24, 1886. There were nearly $a$ hundred persons present. The state was forty years old but the pioneering darys were fresh to the memory of many. The state capitol was almost completed and only a few of the departments were in the old temporary capitol.

It was a notable convention, a meeting of prominent and forceful men. There were several who had been members of the territorial legislatures and one who was conspicuous in the very first one held. A majority of the men had been prominent in the public service or in private life through many years. Here was a man who was builder of the capitol, another who helped organize the state, editors who had participated in the struggles of early statehood, judges, educators and preachers and city and railroad builders. The reunion included sessions in the two halls of the General Assembly and many fine speeches were made. By resolution the officers elected were asked to call another meeting to be held four years later, which was done. 
This first reunion came to an abrupt end in an unhappy climax that forcibly pressed upon the attention of everyone the frailty of human life and the imperative need for securing of the pioneer lawmakers a record of their own notable contribution to history. The joint meeting with members of the House of Representatives was about concluded when Judge James L. Mitchell arose to speak. He had been $\alpha$ member of the Ninth General Assembly and later had gone to Nebraska after a brilliant career as a soldier of the Union army. Judge Mitchell was making the final response to greetings and had just said:

"I revere the men and the labors of the Ninth General Assembly and I must ever love the patriotism and heroic devotion of the Iowa soldiers."

His voice then fell to a whisper, and, as he remarked that he had already spoken too long, he fell to the floor of the House and never spoke again.

The present writer has a vivid recollection of the consternation of the tragic incident; and later had the pleasure of assisting Mr. Aldrich in preparing for publication the report of the reunion.

This tragic episode served to focus attention in all parts of the state upon the meeting of those pioneer public servants, and to remind one and all of the great services they had rendered, of which too little was fully known.

The years that followed were fruitful in arousing much public favor for the work being done. The elder statesmen were thoroughly committed to the support of what seemed to be in the mind of Mr. Aldrich, but which had not as yet been formed into a plan. Great interest was shown by the newspaper editors, partly because of their affection for a fellow editor with a vision, but more so because his work was right in line with their daily task of recording history as it was being made. The autograph collection already made was the source of material for a number of interesting newspaper and magazine articles and had attracted attention in other states.

The second reunion resulted in the formation of the Pioneer Lawmakers Association, which has been continued 
to the present time. This reunion met in February, 1890, when the Twenty-Third General Assembly was in session. The attendance was large and the personnel was of the same distinguished character as that which had been seen at the first reunion. At the outset the following resolution was offered and passed unanimously:

Whereas, by reason of long neglect and indifference on the part of our former authorities and our citizens, many valuable records, pamphlets and other documents have either been destroyed, lost or gathered into public libraries abroad, therefore be it

Resolved, that it is the sense of the Pioneer Lawmakers of Iowa in session that the General Assembly be earnestly invited and urged to take immediate steps to collect and preserve all documents written or printed pertaining to the history of the Territory and State of Iowa.

There was the usual courtesy session with the two houses of the General Assembly and a number of able speeches recalling the legislative work of past years. Mr. Aldrich, who in the meantime had moved into the state library with his autograph cases, invited those attending the reunion to visit the same and look over the collection. Afterwards the following indorsement was adopted:

Resolved, that as the early history of every state is a matter of great importance, and the historical collection in the state library, known as the "Aldrich collection," is now and in coming years will be of great value, and the time and labor necessary to be spent in attending to the same, are more than any private citizen can afford to give without a compensation, therefore we respectfully ask the General Assembly to make sufficient appropriation therefor.

The legislature did take notice of this modest request and provided funds to buy more cases and to give $\mathrm{Mr}$. Aldrich a very modest wage to be superintendent of the same for two years.

Governor Larrabee in his message to the General Assembly in 1888 had indorsed the work being done, and Governor Boies two years later did the same. When the third reunion was held in February, 1892, a bill had already 
been introduced by Senator Charles H. Gatch of Polk County, and this was indorsed by the association, which further added,

Especially do we approve of the main feature of the bill, which is to appoint a curator of historical collections, who shall, in the language of the bill, proceed to collect and arrange books, maps, charts, public documents, manuscripts and other papers and materials illustrative of the history of lowa in particular and of the west generally.

With this backing the bill quickly passed the Senate unanimously and the House with very little opposition, and it was approved by the Governor on April 8, 1892. Thus was the Department made a part of the work of the state itself.

The bill authorized that three rooms in the basement of the state house be set apart for this new Department and that for two years there should be an appropriation for each year of $\$ 7,500$, and thereafter $\$ 6,000$ annually for support and to pary the cost of additions and upkeep.

Charles Aldrich was appointed curator by the board of trustees for the state library and was given a salary of $\$ 1,200$ a year. He named B. F. Gue, former lieutenant governor, as his assistant, and they went to work the first of July following.

The new department of the state grew with amazing rapidity. More cases were bought and filled. Newspaper files were accumulated rapidly. The collection of oil paintings of prominent men got under way. A library was organized. Valuable gifts had been made to the Department. But for lack of room the state was continually losing valuable material. The need of a hall for a natural history and science museum for the state at the state capital had become apparent.

Curator Aldrich stated in his first formal report to the General Assembly that the construction of a memorial hall or historical building "would seem to be a great public necessity." Iowa was entitled to have and maintain a state historical museum, and it should be kept growing, for as 
he said, "a finished museum is a dead museum." And he added:

There is apparently no end to the amount of materials which may be readily obtained for this purpose. The great need is a place in which they can be safely kept and conveniently exhibited.

The appeal fell upon deaf legislative ears, but the editors and public men had heard, and they kept up agitation.

One of the first things done under direction of the trustees for the Department was to resume publication of The Annals of lowa, a quarterly journal of historical information. This was commenced in 1893 after several years of abandonment. It was the plan of the curator and trustees to have the state publish an organ for dissemination of historical information with sufficient state support to keep it free from any commercialism or bias.

The difficulties in the way of securing a state historical building were great. There was no place for it on the state house grounds. The only other land owned by the state was not well located. The legislators were quick to respond to askings for institutions anywhere in the state except at the seat of government. The up-state prejudice against anything that might even incidentally be of benefit to the capital city of the state was strong. Mr. Aldrich, who had been a legislator, well understood the seriousness of this handicap to his plans.

To illustrate the situation and to indicate the resourcefulness of the curator, let us follow his footsteps. The present curator visited the Department on one of his periodical visits to Des Moines, having transferred his activities from the Iowa State Register under James S. Clarkson to the Sioux City Journal under George D. Perkins. Mr. Aldrich explained to him his desire to secure newspaper publicity for his project for a historical building. He could get fine publicity through the Des Moines newspapers, of which there were four, but to do so would almost certainly react against his plans. He knew there were jealousies that 
would decry the suggestion as merely another evidence of the selfishness of the people at the capital city.

The upshot of it was that upon return to his desk in the editorial rooms of the Journal the present writer prepared a journalistic boost for the movement, and Mr. Perkins used it as an editorial. Mr. Aldrich made that the basis of a statewide campaign and held it up as evidence that the move was something that did not originate in the capital city. The ruse worked, and Mr. Aldrich went before the next legislature asking for money because of a demand that came from all over the state.

The Twenty-Sixth General Assembly, in an act approved April 17, 1896, authorized the purchase of ground for a "memorial, historical and art building" and made an appropriation to start the work. The act was defective, but the next year when the same legislature met in special session for another purpose the act was repealed and another substituted, under which the work was commenced. True to form the legislature had made an appropriation entirely too small, and from time to time more money had to be secured by dint of hard begging and weary lobbying.

On the site of the present Des Moines Public Library, the State of Iowa owned a small building on the west bank of the Des Moines river which was used as an armory for the National Guard. This was sold to provide purchase money for the ground for the new historical building. The site bought was that of the old home of Harrison Lyon, one of the men who secured the location of the state capitol in Des Moines by donation of land and money.

The corner stone was laid May 17, 1899, while the work was well under way. John A. Kasson, American statesman and diplomat, delivered a notable address, in which he said:

In recent years the importance of historical collections has been more and more appreciated as aids to education, and it marks an epoch in our local history when the State supplements the general educational advantages of our State university and colleges and schools with the foundation of $a$ historical museum freely accessible to all its people. We may confidently hope that the citizens of the State will ac- 
tively cooperate in its development here, as elsewhere in the Union, by liberal contributions to its enlargement. The Historical Department, for which the State is providing a home, will be an important auxiliary in the development of the higher education of our future citizens.

Before the first of the next year the Department had been moved into the new building and a fresh start was made in the task of expanding and enlarging the divisions to meet the growing demand. It seemed to be almost the culmination of the life work of the founder.

The west wing of the Historical Memorial and Art Building, as it had been called, was hardly completed when the Department was compelled to move into it because of pressure for more office space in the capitol. But other appropriations followed and by 1912 the entire building had been completed and occupied. The cost had been about $\$ 375$,000 , but the value of the material placed therein could only be stated in millions.

The Iowa State Library then and for many years in charge of Johnson Brigham was assigned rooms in the new building, but the law division retained the old quarters near the supreme court rooms. Later the Iowa Library Commission was assigned space for the traveling library and as headquarters for library work out in the state. The medical division of the library also secured a place in the building. There was some embarassing confusion due to the placing of the Historical Department and the library activities under one board, and especially because the entire membership of the supreme court was on the board, which made it certain that the law division of the library would generally receive first attention. There was an unfortunate mingling of appropriations and no clear division of duties and responsibilities. But all who were concerned were loyal citizens and deeply interested in the work, and it early became evident that if the old story of losses by neglect and inadequate facilities was not to be repeated, there would have to be a great expansion in available rooms and working force. 
Not until in 1906 was it recognized that a vital part of the historical museum must ever be the archives, or public records of the transactions of the state with its citizens, and an archives division was established, and definite work on the archives was undertaken.

At some point in the general development of the work, the present historical and genealogical library was definitely separated from the state library and a new line of work commenced. The State library was first a Territorial library, and Congress had bought the books with expectation that they would always remain as a State library for reference purposes. Such of the books as had special significance in lowa history became the foundation of the new library of the Department. To these were added the books by Iowa authors, the books of science and history that would be useful to students of Iowa and the collection of family histories used in genealogy.

Mr. Aldrich as a newspaper editor quite naturally began early the collection of files of Iowa newspapers and all this was placed under the Historical Department; and now the newspaper division is of surpassing importance to all students of Iowa history and people. The enlargement of the natural history and scientific museum, the addition of war records and materials, and the enlargement of the collection of oil portraits, all followed as a matter of course.

In realization of his own declining strength, Mr. Aldrich had induced Edgar R. Harlan to come into the Department with a view to the succession in the post of curator. Upon the passing of Mr. Aldrich, March 8, 1908, Mr. Harlan continued as he had been before, an assistant actually in charge of the work, and a year later he was made curator and commenced the great work of expanding the Department much as planned by the founder but along many new lines.

Edgar Ruby Harlan was suited to the task as perhaps no one else at that time. He had grown up in surroundings that suggested the romance of Iowa history. He had studied law at Drake university and opened a law office 
in Keosauqua. He had married, and his wife was daughter of a venerated pioneer of Van Buren County. Mr. Harlan was elected county attorney. But he was interested in history and helped his father-in-law, George C. Duffield, in the preparation of some articles for The Annals of Iowa. Mr. Aldrich and Mr. Harlan quite naturally came together, and the latter made the sacrifice of giving up a promising career at the law for the harder and less remunerative labors of a historical collector and compiler.

Curator Harlan was familiar with every detail of the work when he was given full charge, under a sympathetic board and state officials who understood the value of historical records. Mr. Harlan had a vision that went far beyond the confines of his growing department. He added to every division. He secured more portraits, more books, more manuscripts, and everything. He became tremendously interested in the Mesquakie Indians living in Iowa, the remnant of the Foxes and a few Sauks, and he not only secured a splendid collection of Indian handiwork but gathered the stories of the Indians themselves and stored away a vast amount of material, the worth of which will be better known in later years.

Mr. Harlan traveled about the state a great deal in search of information and became deeply impressed with the need and the possibility of a vast system of state parks. $\mathrm{He}$ actively entered into the movement to create such a system and was for years secretary of the park board engaged in starting this work. His foresight led to the making of many of the parks and his untiring energy was largely responsible for the system and the general conservation movement of the state.

To Mr. Harlan is due a large part of the credit for the enlargement of the state capitol grounds. The state house had been completed in 1886 but by reason of the expansion of Des Moines in other directions the surroundings of the same were of a poor kind and in many respects a disgrace to the State. Mr. Harlan joined with others in a move to change this situation. A hard fight was necessary to 
secure the authority for the enlargement, and after it was done there was much bitterness and an effort to make use of the improvement for political purposes. But in the end the capitol park was enlarged to about ninety acres and it is now the pride of all Iowa people.

In this work, Mr. Harlan had the active and effective support of Geo. W. Clarke, who had been elected governor.

Mr. Harlan was fortunate in having the confidence of the late Gen. Grenville M. Dodge, distinguished civil war commander and the engineer for construction of the Union Pacific Railroad. His official records and the gifts that marked his notable career are in the Department. It is a very valuable collection and a room is set apart for this alone. Through the gifts of Gen. Dodge there was built on the capitol grounds the beautiful Allison monument. A fine portrait of the General adorns the Department library.

Another room set apart is the Emerson Hough room, with valuable material contributed by that Iowa author. Mr. Harlan also fitted up the Davenport room, with excellent articles of historical value, the gift of members of the family of founders of the City of Davenport.

Publication of the quarterly journal of historical information, The Annals of Iowa, had been taken up after abandonment for a time, by Mr. Aldrich, and Mr. Harlan continued this with much ability. He called to his assistance, David C. Mott, who was a veteran newspaper man who had served in the legislature from two different counties. He maintained the high character of the publication and added to the historical collections.

The archives division was always a problem. Under Cassius C. Stiles, the state records were rescued from the hidden places and an orderly system adopted that has been the pattern elsewhere. Now other states are building up archives departments and the United States government has engaged in the same work. Iowa has a splendid collection of the records of census enumerations commencing in territorial days and these have become precious.

The growth of patriotic organizations and the calls for 
information as to ancestors of the Revolutionary or Colonial times, indicated need for developing a good library of genealogy and family history. This task fell to Alice Marple, who entered upon it with tremendous zeal and enthusiasm, with the result that the Department now has a library of genealogy that is consulted not alone by Iowa people but by those from states far to the east or the west.

The museum of natural history and science was in charge of Joseph Steppan for many years, and it is a mine of information for students of bird and animal life, geology and archeology, Indian customs and equipment, military affairs, guns, weapons, pioneer implements and utensils; and this mine is being worked every week by school and college students from all parts of the state.

In addition to those mentioned already the Department has had the services of Ellen D. Spaulding, Mary B. Whitcomb, Alice M. Steele, Martha Watson, Ida M. Huntington and Halla M. Rhode in various capacities and all contributed much to the collection.

The newspaper collection got an early start and it is especially fine in the files of early state newspapers. There has been neither money nor available room for properly caring for this collection, and it is inevitable that resort must be had to the filming process to keep the record as desired.

In the work of enlarging the portrait gallery of eminent men and women of Iowa, the curators engaged in much personal work, with the result that Iowa has a wonderful collection of these portraits. The help of many volunteers contributed to this splendid gallery.

Mr. Harlan continued as curator until March, 1937, and he lived in retirement until July, 1941. Mr. Aldrich and Mr. Harlan piloted the Department for full forty-five years. The one could properly be called the founder and the other the builder of the Department. In the brief period when Professor Benj. F. Shambaugh, of Iowa City, was nominally curator, the work was actually in charge of Mr. Harlan. For two years after Mr. Harlan's retirement, O. E. Klingaman was curator, and he carried on in the spirit of the founders 


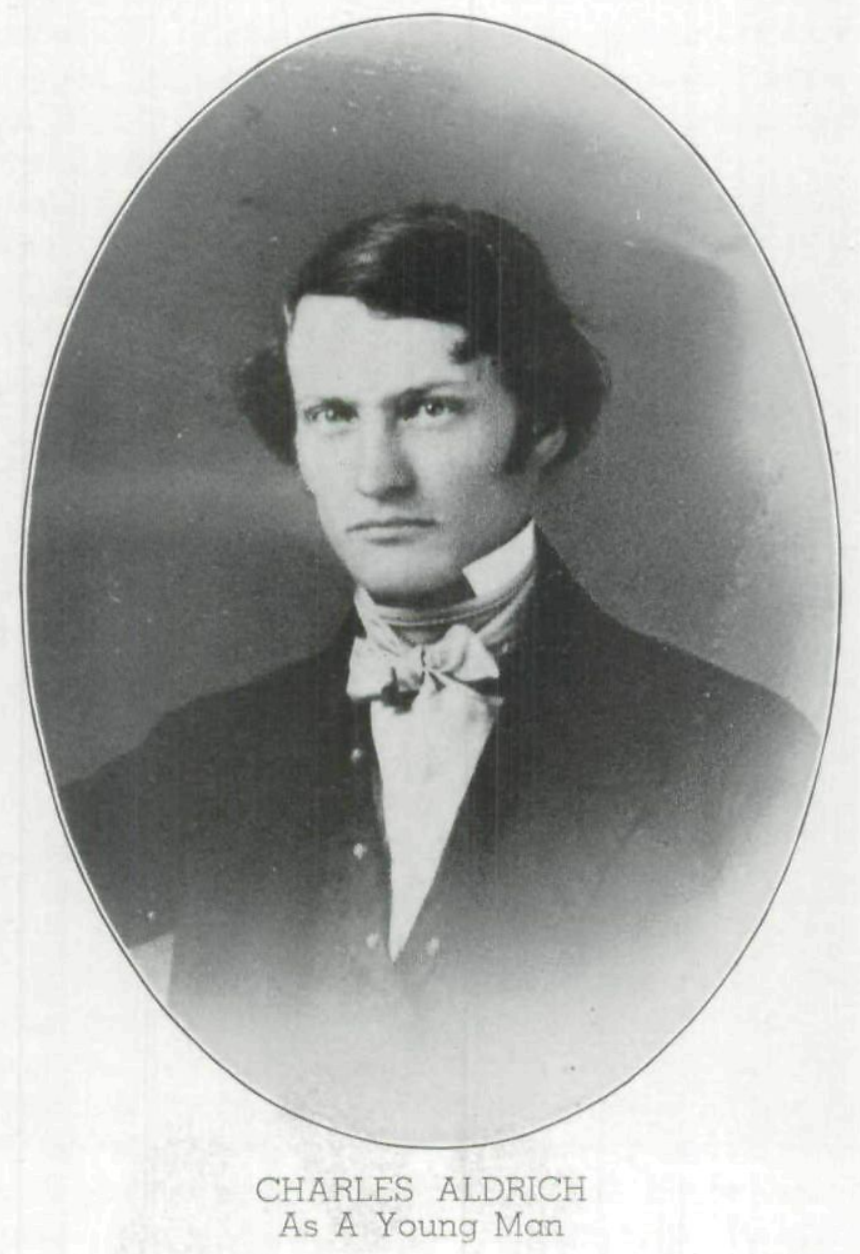




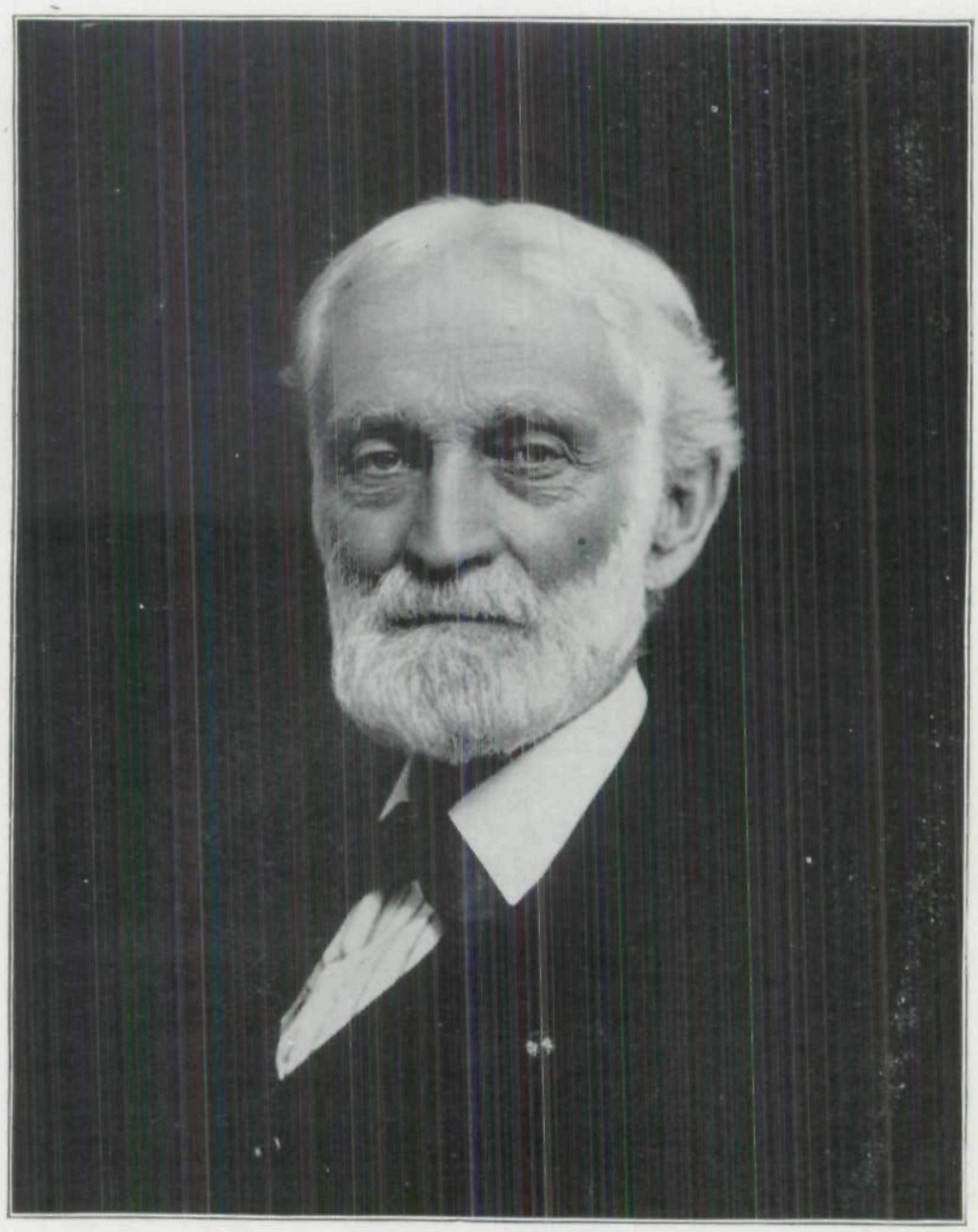

CHARLES ALDRICH

As Curator of the Iowa Historical Department 

erans of the Rainbow Division, this old film has been made over into a sound film, in great demand.

Under the Act of Reorganization of 1939, the board of trustees having full control of the Department was made to consist of only three persons, the Governor of the State, the Superintendent of Public Instruction, and a member of the Supreme Court. The court ordered that the chief justice should be the member of the board of trustees, which causes a rotation and change once each half year. The trustees are also a board of management for the other state libraries.

The reorganized board of trustees of the Iowa State Department of History and Archives, as it was now called, in March, 1939, elected the writer to be the curator.

The addition of the name "archives" to the official title of the State Historical Department was to emphasize the close relation of the entire department to the archives and all the archival material not previously lost. Several of the governors had called the attention of the legislature to the need of an archives department and a building in which to keep the material. The space available in the state historical building for archives was never sufficient, and long ago it was a crying need that an archives building be erected. When the legislature adopted the plan for the state capitol extension and fixed by law the location of buildings, an archives division was included, which would be an annex to the historical building. No appropriation was made for same, however, because of the insistent demands of groups seeking other recognition.

The biennial report of the Department for 1938-1940 strongly stressed the need of more working and storage room for the archives. The books, papers, letters and other material were accumulating rapidly. The vacant places in the attic and basement of the capitol had been filled, various tunnels for heating pipes contained tons of material, every closet and nook in the historical building was crammed with papers and there were several rented rooms used for storage or for work. A building for the 
proper keeping of archives must be specially constructed for that purpose and not otherwise. Such a structure should be entirely different from an office building and conditioned for the safety and preservation of papers and books. Iowa is now far behind many other states.

A partial recognition of the archive problem was made by the legislative retrenchment and reform committee, in securing on a rental basis the use of the "John A. Kasson Memorial Hall", only a block from the historical building. It was taken over for the use of the department in February, 1942. It will serve well as a work room for many of the projects being carried on under the direction of the Department and some of the material from the various offices can be placed there, but not all. At best it will be only slight relief from the pressure for more room for the business of the state in this special field.

There is a certain appropriateness in the taking over of the "Kasson Building" as a part of the State Historical Department. No one ever showed more interest in the Department than did Mr. Kasson. He delivered a notable address at the laying of the corner stone. He gave a magnificent portrait of himself to the art gallery. His personal correspondence is in the department. He was a great American diplomat and helped write the platform on which Lincoln was first elected. He gave the funds for the building of the structure now taken over, having planned it first for a community house under control of the neighboring church. Certainly if Mr. Kasson could have had his wish he would have asked for nothing better than to have the building he caused to be erected used for the historical work of Iowa.

The State Historical Department, as it has always been called, occupies a building declared by many to be the most becutiful of any public building in Iowa. It does not occupy all of the building, owing to the lack of office space in the capitol or elsewhere. The Department has grown in magnitude far beyond the dreams of its founders and this growth has been largely the result of persistent and indefatigable labor on the part of Curators Aldrich and Harlan, 
almost always working under the handicap of insufficient funds and facilities.

Before the Department was established there had been irreparable loss to the state by dispersion or loss of valuable records. Much valuable matter was gathered up and sent to other states or to places where its care has not been possible. By its nature the Department must ever be free from political influence, and neither the trustees in charge nor the curators were in a position to bring pressure for legislative appropriations. The result was that the Department suffered many vicissitudes and especially in its duty as the conservator of public archives there has been gross neglect.

Mr. Aldrich was so deeply in earnest that he gave his time freely to get started and after he had given his valuable collection to the State he was not compensated for the care he gave to the same. When the Department was established and some rooms given him, he was given a salary of $\$ 1,200$ a year, and the highest he received was $\$ 1,600$ a year. By the time Mr. Harlan was placed in full charge the salary had been increased to $\$ 1,800$ a year, and finally by the year 1919 the salary had been increased to $\$ 3,600$ a year, which was less than that paid in many other states for similar responsibility. In the period of depression, Curator Harlan took a voluntary reduction to $\$ 2,400$ a year, along with a general scaling down of all salaries in his Department amounting to one-third. In 1941 this was raised to $\$ 2,700$ a year.

The curator has the custody and care of the building and its collections, and these latter have an actual value estimated at far above a million dollars; and the service in response to calls from an almost infinite variety of sources demands the daily use of a storehouse of information obtained only by years of preparation. Both the founder and the builder of the Department possessed rare qualifications for this important task.

At the beginning, the Department was allowed $\$ 6,000$ a year for payment of salaries and support, which was in- 
creased when to the Department was added the duty of custodianship of the building. By 1929 the annual allowance was $\$ 49,550.00$, and with this sum the Department was able to conduct investigations and make purchases of valuable materials. The depression period brought the annual appropriation down to $\$ 28,979.00$, and for the period 1941-3 it is $\$ 30,563.00$. At present more floor space is given over in the building than ever before to activities other than the Historical Department, and the custodial work has increased as well as the general activities in historical and museum work.

In the past four years much long neglected work was done through federal agencies, under projects opened by the late Curator Klingaman, including a historical records survey, some valuable compilation and publication of history, the indexing and classifying of state records and the official papers in the Department. The Department has cooperated fully with all the federal agencies and the result is invaluable. However, this has now been discontinued.

The disposition on the part of the public, at least as far as reflected in legislative circles, has been to disregard the commercial value of the Department and to treat it as an interesting but expensive ornament. But it has been demonstrated that the Department has a value entirely apart from its sentimental appeal or historical service.

The availability of the records for use in courts and elsewhere in legal proceedings or investigations has been greatly enhanced by the archives work done in recent years, and it is certain that in actual money value to the State itself the Department is a good investment. The incidence of the war with Japan and Germany has made heavy calls upon the Department for census and other records and the continually growing interest in family history and genealogy to meet the needs of patriotic groups makes heary drafts on the working force.

The Department is this year, 1942, celebrating its semicentennial as a state institution. There is much cause for gratification over the progress made in many directions. Perhaps best of all is the general recognition of the Depart- 
ment as a part of the general educational system of the state. The number of visitors increases with the years. Many school and college groups of young people visit the building to supplement their facilities for study of Iowa history, pioneering, geology, natural history, Indian life, archeology and natural resources. They come to consult the library and to become familiar with the portraits of the men and women who have built Iowa. They make use of the newspaper files, the historical manuscripts and collections, the records of the state in all lines.

The Aldrich collection remains, however, the very center and heart of the Department. Here the student of American life, and for that matter all Nineteenth century life, can see the handwriting of many of the eminent persons of the past century and a half, with portraits, manuscripts, letters and other material. All this ties in with the splendid library of genealogy and history and the task of getting out THE AnNALS OF IOWA quarterly as the state's medium of information on historical matters.

The State Historical Department's first fifty years show accomplishments that are a matter of great pride to the people of Iowa. It is no longer a hobby, it is an institution. 


\title{
THE TELEPHONE IN IOW A
}

\author{
By Charles C. Deering
}

In 1875 Alexander Graham Bell, Scotsman by birth, American by adoption, invented the electric telephone and applied for a patent.

Bell was a teacher of acoustics and a student of electricity.

His invention came as he was seeking to devise a multiple telegraph.

The apparatus he made in 1875 transmitted sounds, recognizable as the human voice, but the first complete and understandable sentence was transmitted in March, 1876, a few days after his patent had been granted March 7 , 1876.

Bell's device was for all practical purposes, the receiver used today. The user spoke in a loud voice into this piece of apparatus and then placed it to his ear and waited for the response - the next step was to use two of these pieces of apparatus as one set, one as a transmitter and one as a receiver.

A company was formed to manufacture telephones and to develop their use. This company determined not to sell telephones, to lease them only, and the origincal company and its successors adhered to this policy until comparatively recent years.

The original telephone was a good receiver but a poor transmitter; however, more efficient transmitters and also signaling devices and then switchboards were developed so that the telephone became a practical thing.

Many people scoffed at the thought of its ever becoming more than a scientific toy, but Bell was $\alpha$ man of vision, and made this remarkable prophecy in March, 1878, only two months after the opening of the first telephone exchange at New Haven, Connecticut. 
Copyright of Annals of Iowa is the property of State of Iowa, by \& through the State Historical Society of Iowa and its content may not be copied or emailed to multiple sites or posted to a listserv without the copyright holder's express written permission. However, users may print, download, or email articles for individual use. 